University for Business and Technology in Kosovo

UBT Knowledge Center

Nov 2nd, 9:00 AM - Nov 3rd, 5:00 PM

\title{
A study on relationship between brand loyalty and customer service in insurance companies companies. The case of Macedonia and Albania
}

\author{
Klijme Poposki \\ President of Council of Expert of the Insurance Supervision Agency \\ Ilir Elmazi \\ Economic and Financial Director of Vienna Insurance company
}

Follow this and additional works at: https://knowledgecenter.ubt-uni.net/conference

Part of the Business Commons

\section{Recommended Citation}

Poposki, Klijme and Elmazi, Ilir, "A study on relationship between brand loyalty and customer service in insurance companies companies. The case of Macedonia and Albania" (2012). UBT International Conference. 39.

https://knowledgecenter.ubt-uni.net/conference/2012/all-events/39

This Event is brought to you for free and open access by the Publication and Journals at UBT Knowledge Center. It has been accepted for inclusion in UBT International Conference by an authorized administrator of UBT Knowledge Center. For more information, please contact knowledge.center@ubt-uni.net. 


\title{
A study on relationship between brand loyalty and customer service in insurance companies. The case of Macedonian and Albania
}

\author{
Klime Poposki, $\mathrm{PhD}^{1}$ \\ ${ }^{1}$ President of Council of Expert of the Insurance Supervision Agency \\ Ilir Elmazi, Phd Sudent, Actuar ${ }^{2}$ \\ ${ }^{2}$ Economic and Financial Director of Viena Insurance company
}

\begin{abstract}
Despite of remarkable interests in the nature and role of marketing application from servicing perspective, there are limited researches on service branding. By describing four major aspects of service branding, present study studies these aspects and their impacts on service conceived quality and finally it investigates the impact of service conceived quality on customer loyalty. Represented model includes the impact of brand traditional image along with other three impacts, that is, company image, employees' confidence and company's confidence. By using a 100-subject sample of Albania and Macedonia Insurance Company's customers, the analyses show that brand image and company's image have direct and positive impact on service conceived quality while a significant relationship is not seen between company' confidence and employees' confidence with service quality. Finally, the aspects of service brand impacts indirectly on customers' loyalty via impacting on service conceived quality. The positive impact on brand image and company's image on service conceived quality are too important due to the fact these two service brand aspects are highly impacted by external marketing as well as the importance of external marketing and throughout campaigns for insurance company via radio, TV and other mass media. In one hand, since most insurance companies are similar in terms of provided services, one can distinguish the special brand of Albanian and Macedonian Insurance in terms of special discounts, discounts on simultaneous usage of several types of insurance, etc. On the other hand, increasing the accessibility to services throug $h$ opening further affiliated branches and full explanations of insurance services - that are typically varied and detailed - in guiding brochures and notebooks lead into customers' awareness and finally into a separated mindset and a positive and effective service brand for the company.
\end{abstract}

Keywords: service brand, brand image, company's image, employees' confidence, company's confidence, service quality, customer's loyalty

\section{INTRODUCTION}

\section{Characteristics of Services in the Financial Markets}

Financial services are not only intangible. They may also be very complex in that they consist of obviously related units, but the degree and nature of their interrelationship is not completely known. Thus, for research purposes, we chose to describe services, and especially financial services, in terms of tangibility, complexity and, a crucial variable in marketing, comprehensibility. The latter refers in general to the customer's ability to fully comprehend the elements comprising the service. We have used Shostack's model above and adjusted it to suit our purposes, modifying it into a financial services.

The more intangible the service the more important the management of relationships, a factor which has to be stressed in the insurance business. Even though all financial services have an intangible dominant, they vary in their degree of tangibility in terms of the consumer's ability to grasp the particular service mentally - to comprehend the service rendered. For example, a credit card is very palpable, lying in the wallet awaiting an increase in the propensity to spend, connected with the knowledge of the card as a symbol either of money in an account or the ability to get credit. Somewhere halfway down the scale is a bank loan. Money is needed in order to buy a house, the bank is contacted, a contract is signed and the loan is a fact, paired with the knowledge that it has to be paid back, together with interest on the borrowed money.

This is not particularly complex to understand, at least not the main thrust of it concerning the financial ability to buy a house. Commercial insurance, however, is at the intangibility extreme.

According to Keller (1993), most researches on brand have been so far focused on consuming goods especially on understanding the effects of brand awareness. There is an emerging trend on branding which is as same as service logic in concentrating on added value processes. In such view, brand plays a broader role so it is related not only to end users but also to company, its employees and its shareholders. Research papers call this broader perspective of branding as "service brand" (Brodie et, al," 
2009). The pioneering research of Berry (2000), which stems from the interpretation of his personal experiences with laborintensive service organizations, provides initial insight into the way brands play a broader role. While Berry's model still recognizes that the awareness of the company's presented brand influences the brand's equity, Berry suggests the brand's "meaning" that the customers derive from their service experiences is more important. Hence, Berry states that "the company" becomes the primary brand rather than the product. Conducted studies have paved the ground to develop this service branding model fruitfully. They indicate that brand creates an "experimental image", a "commitment to experience servicing" and "communicational confidence". Together thesethree studies highlight the need to have a broader conceptualizationwhen rethinking the traditional image and logo view of the brand(Berry 2000). The purpose of present study is to understand the nature of service brand by using a quantitative study. The empirical ground for present paper is insurance industry. By providing a theoretical framework on brand concept, its aspects and its relation to service quality and customers' loyalty, present paper studies service brand by using the same framework in insurance services. To this end, several branches affiliated to Asia Insurance Company in Kerman are considered and relevant questionnaires are dis tributed among them.

\section{Developing a conceptual framework on service brand}

Some authors consider the role of fulfilling commitments on brand. Amber and Styles (1996), for example, define brand as a "commitment on a set of traits bought by someone" which "maybe fantastic, logic, sensational, tangible or intangible". By providing a concept of commitment, Balmer and Gray (2003) conclude that "the core of a legal brand consists of a revealed commitment between organization and key stockholder groups". Branding is an important concept in trading activities and academic researches. It is for the same reason that successful brands help market-owners to acquire a competitive advantage which includes opportunities to increase market share successfully, resilience aga inst competitors' developmental pressures and the capability to create entry barriers for rivals. Branding mitigates customers' risk feeling during buying the services. Likewise, a high level brand enhances customers' satisfaction and loyalty degree (Kim et al., 2008).

Brand value comes from knowledge structures which may have their own aspects. According to Aaker (1997), these aspects include brand awareness, brand contribution, conceived quality and brand loyalty (Kim \& Hyun, 2010). On the other hand, brand value in trading markets plays a major role under some aspects of trading exchanges. Researches show that brand value is a strong survival stimulant for consuming, industrial and servicing markets (Kottler \& Pfortsch, 2007).

To develop a conceptual framework for service brand, initially developed model by Calonius (1986) is accepted (figure 1). Employees and customers are inside the framework of external, internal and interactional activities of the organizational regarding organizational brand conceptions. The same framework describes service brand such as playing a complementary role via integrating the attitudes and conceptions of employees and customers of organizational brand (Brodie et al., 2009).

Three marketing processes include:

1. External marketing (the relationship between organization and customers via establishing commitments on service providing).

2. Interactional marketing (interactions between those individuals who are working in organization and end users via creating the experience on continuous purchase and commitments on service providing)

3. Internal marketing (including organization and those individuals who are working there - commitments on service providing)

\section{Service quality}

Supplying higher quality services and providing customer with continuous and excellent services lead into competitive advantages for service organizations. Most important competitive advantages include competitive barriers, supplying outstanding products, mitigating marketing costs and customers' loyalty (Rusta, 2008: 4 -9). Reviewing relevant literature indicate that major concerns on service quality can be divided into two parts: recognizing quality aspects and developing tools to measure service quality in researchers' future efforts. Then, an operational plan on service quality is rapidly increased by testing such results as attaining the customers, attracting new customers from face-to-face advertisements, rising the productivity, improving market share, reducing employees' repetitive efforts, mitigating operational costs and enhancing profit making (Kuo et al., 2009). In present paper, service conceived quality defined as customers' judgments on an advantage compared to considered quality. According to Parasuraman et al (1997), conceived quality is a type of relevant but unparallel to satisfaction attitude as well as the results of comparing expectations to performance conceptions.

According to studies by Lefkowit and Clark (1998) and Morrall (1993) to distinguish services as similar as goods, one s hould not only distinguish them in terms of name or logo but also in terms of a set of customers' conceptions that are defined well. To achieve such aim, Camp (1996) suggests controlling all aspects of interactions between brand and target market. Similarly, Sanders and Waters (1993) agree that branding gives a name to products (goods or services). Sanders, Waters (1993) and Camp (1996) believe that branding is on determining a target market and then to develop a product and brand character (Bei et al, 2006). In studies by Dall'Olmo Riley and de Chernatory (2000), 9 major fields were recognized in relation to brand:

(1) Legal tools

(2) Logo

(3) Company

(4) Identifying system 
(5) Image in customers' minds

(6) Character

(7) Relations

(8) Added value

(9) Institutional revealing

Brand image namely the relations are available that cause brand and logo awareness and distinguish them from services. Then, there are relations on company's image which involve company's credibility rather than service providing characteristics. In provided conceptual framework, there is a difference between customer's trust to the behavior of service providers or custome rs and customers' trust to operation and managerial policies of the company (Brudei et al, 2009).

\section{Brand image}

Thaker (2006) explains that brand image can be a thought of natural traits and it has a special relation to brand identity co ncept. Aaker defines the brand identity as a set of human traits weaved in a brand. Personality stimulation assessments explain why a consumer may keep emotional dependency to a brand but not to another one (Brodie et al, 2009).

\section{Company's image}

In a preliminary study, Brown and Dacin (1997) show that company's image is emanated from customers' conceptions, competencies and social responsibilities. Company's competency is recognized by its expertise in product manufacture and delivery. Social responsibility refers to management of society-related affairs.

\section{Company's trust and employee's trust}

Dony and Canon (1997) defined trust as conceived credit of a sector. The focus of the first aspect is on the believing capability of a contributor in relations. The second aspect concentrates on how a contributor is interested on his or others' welfare (Kim et al, 2008). In this study, customer's idea company's image is distinguished from his trust on service delivery. Overall, company's image is customer's image of commitments by the company on its social competency and responsibility. This is a general view on company which impacts highly on external relations. In contrary, customer's trust is more focused and on the basis of experience and reflects customers' interaction to company and its employees in service delivery and experience. Therefore, customers' experiences are particularly related to the operations and policies of management and staff (Brodie et al, 2009). Considering provided framework on marketing and explanations on brand aspects, one can conclude that two brand image and company's image aspects are related to external marketing and employees' trust and company's trust are related to interactional marketing. According to results of analyzing the hypotheses, one can plan for these two groups of marketing activities. Discussions on internal marketing are beyond the scope of present study.

\section{Loyalty}

Richard Oliver (1977) defines loyalty as: "it is a strong commitment to superior services or goods repurchase in future to ac quire the same brand despite of marketing efforts by potential rivals and their impacts (Hamidizadeh and Gh amkhary, 2009).

This definition may be limited. In fact, customer's commitment is the outcome of an organization which creates advantages for customers so that they keep on increasing their purchase from the same organization. Real customer's commitment is established when he/she is motivate to purchase without any encouragement. This relationship is established if parties feel that there are special advantages for them and they can attract each other like two poles. Loyal customer does not only focus on p rices but also he/she acts like a fan of organization and, as a result, helps to attract new customers (Zare, 2008). Likewise, the cost to a cquire a new customer is 15 times of retaining an existing customer (Fahimi, 2006) and by \%5 increases in customers' loyalty; the profit also increases $25-85$ percent (Hamidizadeh and Ghamkhary, 2009).

To acquire customers' loyalty, one should initially have an image of the customer. At the outset, the organization has one customer and protects him/her by respect and mediation. Then, it uses any relation as an opportunity to establish loyalty. With regard to customer's loyalty, the goal is to enhance the relationship between customer and organization in the condition of passing different steps of managing the relations with customer. Hence, customer's satis faction grows and the value of relations will be increased among parties. This is the same thing which leads customer to loyalty enhancement. If organization continue s to meet customer's needs and to provide its services in a manner which motivates permanent demand, then a bilateral value will be established and the final target namely customer's dependency or strategic management of relations with customer will be achievable (Colwell et al, 2009). Findings of Sirdeshmukh et al (2002) indicate that customer's value is a key affecting factor on customers' loyalty in airlines. They support Holbrook (1994) who said customer's value is a fundamental base for marketing activities. Churchill (1997) states that brand loyalty are customer's preference to buy a certain brand. Jaccobi et al (1974) state that brand loyalty differ from brand habit or view though these can determine brand loyalty in next steps. Kim et al (2008) findings on affecting factors on customers' view in hos pitals indicate that such factors as customer satisfaction, communicational 
commitments and confidence have a remarkable impact on brand loyalty and awareness and a positive impact on customer's view to hospital.

\section{Customer Loyalty and the Return on Relationships}

Today a company's market share is often considered less important than its share of customer (cf., Gummesson, 1997). This refers to how much of the customer's potential engagement with the services the company is able to provide is, in fact, realised and managed (a low share of potential engagement indicates customers who buy from many sources). As Goldberg (1997) noted, a customer must be "viewed and managed not as part of a large, homogeneous mass but rather as a unique individual representing a unique business asset" (p. 29). Consequently, service companies are trying to think in terms of possible ways of measuring the financial implications of customer loyalty, as well as maximising the lifetime value of the customer to the companies. Some ideas influencing approaches to the building of customer loyalty are to sell more than a product; to be a partner, not just a vendor; to walk in the customers' shoes to understand their situation; and to decrease employee turnover in order to retain customers.

Understand and solve a customer's business problem and the relationship is deepened. Customer loyalty may be considered a key to profitability, but it is reasonable to state that the creation of this sense of loyalty is not something that happens overnight. As an example of this, there is research showing that in certain private insurance business it may take as long as seven years before the individual customer gives the provider any profit from the relationship (Gummesson, 1996). The "loyalty management guru," Frederick Reichheld, proposed accordingly that profit is not the primary goal. Although indispensable, profit is the consequence of value creation, which, together with loyalty, are the cornerstones of long -term relationships (Reichheld, 1996). The mission ranked at the highest level of priority in a loyalty-based effort is to make sure that the company finds and keeps the "right" customers. The right customers are mainly those to whom the best value possible can be delivered by the company over a long-term period. The effects of marketing alone are not able to create sustainable loyalty; customers stay loyal because of the value they receive, not because of a marketing program. Hence the role of the marketing department is "to ensure that the efforts of each department are coordinated into effective delivery of a unique value proposition, which will provide superior value a nd thus, earn customer loyalty" (Reichheld, 1995, p. 238).

An enhanced level of customer loyalty includes the benefits of increased revenues from repeat sales and referrals and increased employee job satisfaction. The Swedish researcher in relationship marketing, Dr. Evert Gummesson, introduced the term return on relationship, defined as "the effect on long term net financial outcome caused by the establishment and maintenance of a company's network of relationships" (Gummesson, 1997, p. 205). The measure not only relates to customer-supplier relationships, but also to competitor relationships. Following Gummesson's reasoning, examples of ways to improve the return on relationships are given below (Gummesson, 1997).

Customer's conception of brand includes brand image, company's image, employees' trust and company's trust. However, customer's conception has other aspects that are not mentioned here. Following hypotheses are provided by assuming that each aspect of brand has a separated impact on customers' conceptions of service quality:

H1: Customer's conceptions of brand image impacts on his/her conception of the quality of provid ed services positively.

H2: Customer's conceptions of company's image impacts on his/her conception of the quality of provided services positively.

H3: Customer's trust employees' behavior impacts on his/her conception of the quality of provided services positively.

H4: Customer's trust to operations and policies of company's management impacts on his/her conception of the quality of provided services positively.

H5: Customer's conceptions of the quality of provided services impacts on his/her loyalty positively.

\section{METHODOLOGY}

In present study, a 37-item questionnaire by Likert's five-scale range is used to investigate the existing relations in Insurance Companies in Albania and Macedonia. At the beginning, 30 questionnaires were distributed to measure the reliability and obtained Chronbach's alpha was \%82. Research statistical population consists of the customers of ten ( 10) Insurance Companies in Albania and Macedonia. Relevant questionnaires were distributed among the customers of various companie s surveyed. Finally, 100 questionnaires were gathered and analyzed. T test and regression methods were used to analyze data.

\section{DATA ANALYSIS}

T test was used to analyze data and, as shown by results, low and high levels are positive for all variables which indicate that responses are higher than mean level (mean level =3) to well and very well levels. Likewise, the significance of all variables is less than 0.5 which shows that considered variables are relevant and important factors in this study. 
Table 1: the average of responses to variables in t-test (mean $=3$; confidence level $=\% 95$ )

\begin{tabular}{|l|l|l|l|l|}
\hline Brand image & 3.4 & 0.00 & 0.34 & 0.63 \\
\hline Company's image & 4.02 & 0.00 & 0.88 & 1.17 \\
\hline Employee's trust & 4.57 & 0.00 & 1.20 & 1.91 \\
\hline Company's trust & 4.34 & 0.00 & 1.22 & 1.47 \\
\hline Service quality & 4.24 & 0.00 & 0.91 & 1.55 \\
\hline Customer's loyalty & 4.20 & 0.00 & 0.05 & 1.32 \\
\hline Variable & average & significance & Low level & High level \\
\hline
\end{tabular}

Table2: research variables linear regression figures

\begin{tabular}{|l|l|l|l|l|}
\hline Brand image & Service quality & 0.41 & 0.71 & 0.002 \\
\hline Company's image & Service quality & 0.46 & 0.81 & 0.000 \\
\hline Employee's trust & Service quality & -0.52 & -0.45 & 0.197 \\
\hline Company's trust & Service quality & 0.169 & 0.45 & 0.085 \\
\hline Service quality & Customer's loyalty & 0.258 & 0.30 & 0.044 \\
\hline Variable & Dependend variable & Standart ratio & Substandard ratio & significance \\
\hline
\end{tabular}

Considering above explanations and table, the results of research hypotheses are provided below:

H1: Customer's conceptions of brand image impacts on his/her conception of the quality of provided services positively and well.

H2: Customer's conceptions of company's image impacts on his/her conception of the quality of provided services positively and well.

H3: Customer's trust to employees' behavior impacts on his/her conception of the quality of provided services positively.

H4: Customer's trust to operations and policies of company's management has partial significant impact on his/her conception of the quality of provided services positively.

H5: Customer's conceptions of the quality of provided services impacts on his/her loyalty positively and low.

Considering the data of above table on employee's trust and company's trust, since the significance level was greater than \% 5 , one can say that these two variables have no significant impact on service quality. Regarding the relationship between these two variables with brand image and company's image, one can conclude that they have well and positive impact on service quality. In the meantime, service quality variable has a positive and direct but not so strong impact on customer's loyalty. Thus, $\mathrm{H} 1$, $\mathrm{H} 2$ and H5 are supported while H3 and H4 are refused since the significance level for employee's trust and company's trust is greater than \% 50. Simultaneous impact of service brand aspects on service conceived quality and customer loyalty is achieved. Findings indicate that $\% 52$ changes in service conceived quality variable $(\mathrm{R} 2=0.52)$ is due to quadruple aspects of service brand and only $\% 7$ of changes are due to errors in sample and model data. Additionally, it became clear that $\% 15.9$ of changes in customer's loyalty $(\mathrm{R} 2=0.159)$ emanated from service brand aspects. Thus, as the results show, service brand aspects impact less on customers' loyalty directly and their highest impact is through quality service variables.

\section{DISCUSSION, CONCLUSION AND RECOMMENDATIONS}

In a research by Kim and Hyun (2010) in industrial markets, the impacts of various factors including price, after sale services, promotions and sale channel on customers conceived quality and the final impact on brand loyalty were studied. The results show that concerned factors have a positive impact on quality and quality also has a suitable impact on brand. In present study, three aspects including company's image, employee's trust (customer's trust to employee's behavior) and company's trust are considered in addition to traditional brand image aspect and their impacts on service conceived quality and finally on customers' loyalty in Albanian and Macedonian Insurance Companies are investigated.

As mentioned before, two company's brand and brand image aspects are achieved through external marketing processes and customer's trust to employee's behavior and customer's trust to managerial policies and operations are achieved via interactional marketing activities. Finally, through field studies and data analysis, it was concluded that brand image and company's image have a well and direct impact on service conceived quality of Albanian and Macedonian Insurance Companies and H1 and $\mathrm{H} 2$ were supported while employee's trust and company's trust have no significant relationship to service conceived quality. Therefore, H3 and H4 are refused. Put it differently, one can conclude that in Albanian and Macedonian Insurance Companies, external marketing activities impact on service conceived quality while interactional marketing activities have no special impact. In the meantime, it is clearly obvious that service conceived quality also impacts positively and directly on the Insurance Company customers' loyalty but its impact is trivial. So, H5 is supported. Past researches show that there is a direct relationship 
between trust and loyalty in B2B and B2C (Erdem and Swait, 2004). Studies by Brodie et al (2008) in an airline indicated the positive impact by brand image, company's image and employee's trust on service conceived quality. It means that there is homogeneity on the confirmation of $\mathrm{H} 1$ and $\mathrm{H} 2$ among the findings of researches at Asia Insurance Company and concerned airline. However, in researches on airline, H3 namely the positive impact of employee's trust on service conceived quality is supported while it is refused in Insurance Companies. In the meantime, a research by Brodie et al (2009) shows that the impact of service conceived quality on customer's loyalty is indirect and as a mediator factor, customer's conceived value highly impacts on customer's loyalty. In another study by Sirdeshmukh et al (2002), the positive impact of the first three factors (brand image, company's image and employee's trust) on service quality are confirmed while company's trust on service conceived quality is negative. Finally, one can say that by increasingly application of service activities in companies and institutes, the need to devise branding strategy for proper services on loyalty - customer's value process is well understood and tangible. These views are compatible to the insights of contemporary authors like Woodruff (1997), Srivastava et al (1999), Rust et al (2004) and all people who have emphasized on customer's value and loyalty as the key resource of competitive advantage. However, in other studies such a study by Gounaris et al (2003) in Athenian banks, the impacts of other aspects except than service brand quadruple aspects on service conceived quality are examined. These factors include face-to-face communication, staff relations and market-orientation. The results show that except than face-to-face communication, other factors have important and determining impacts on service conceived quality of Athenian banks (Gounaris et al, 2003). Overall, one can conclude that service conceived quality and customer's loyalty are not only impacted by customer's conception of brand and there are paramount factors that can impact on them. Anyhow, the impacts of brand aspects on services are fully observable and non negligible and it is now highly discussable in service organizations particularly competitive arenas as a vital factor.

The positive impact on brand image and company's image on service conceived quality are too important due to the fact these two service brand aspects are highly impacted by external marketing as well as the importance of external marketing and throughout campaigns for insurance company via radio, TV and other mass media. In one hand, since most insurance companies are similar in terms of provided services, one can distinguish the special brand of Albanian and Macedonian Insurance in terms of special discounts, discounts on simultaneous usage of several types of insurance, etc. On the other hand, increasing the accessibility to services through opening further affiliated branches and full explanations of insurance services - that are typically varied and detailed - in guiding brochures and notebooks lead into customers' awareness and finally into a separated mindset and a positive and effective service brand for the company.

\section{REFERENCES}

Aaker J (1997). Dimensions of brand personality. J Mark Res;34(3):347-56.

Ambler T, Styles C)1996(. Brand development versus new product development: towards a process model of extension decisions. Mark Intell Plann;14(7):10-9.

Balmer JMT, Gray ER(2003). Corporate brands: what are they? What of them? Eur J Mark ;37(7/8):972-97.

Berry L(2000). Cultivating service brand equity. J Acad Mark Sci;28:128-37.

Australian Journal of Business and Management Research Vol.1 No.6 [152-158] | October-2011 158

Brown J, Dacin P(1997). The company and the product: corporate associations and consumer product responses. J Mark;61:6884.

Brodie R, Whittome J, Brush G (2009). Investigating the service brand : A customer value perspective. Journal of Busine ss Research.. No 62 . pp 345-355

Bei L and shang $\mathrm{F}(2006)$. building marketing strategies for state-owned enterprises against private ones on the perspectives of customer satisfaction and service quality.Journal of Retailing and Consumer Services. No 13.pp 1-13

Calonius H. A market behavior framework. Paper presented at the 15th annualconference of the European Marketing Academy (EMAC), Swedish School ofBusiness and Economics, Helsinki, Finland 1986; 515-524 (reprinted in MarketingTheory 2006; 6 (4): 419-428).

Colwell S, JaingD and Hogarth-Scot S(2009).Effects of organizational and Serviceperson orientation on customer loyalty. Journal of management Decision .vol 47. No 10. pp 1489-1513

Dall'Olmo Riley F, de Chernatony L(2000). The service brand as a relationship builder. Br J Manage;11:137-50

Doney P, Cannon J(1997). An examination of the nature of trust in buyer-seller relationships. J Mark;61:35-51.

Erdem T, Swait J) 2004(. Brand credibility, brand consideration and choice. J Consum Res ;31:191-8

15. Gounaris s, stathakopoulos v, athanassopoulos A(2003). "Antecedents to perceived service quality: an exploratory study in the banking industry". international journal of bank marketing 21/4 168-190

Holbrook M(1994). The nature of customer value: an axiology of services in the consumptionexperience. In: Rust R, Oliver R, editors. Service quality: new directions in theory and practice. Newbury Park, CA: Sage Publications; 
Keller K(1993). Conceptualizing, measuring, managing customer-based brand equity. J Mark;57(1):1-22.

Kim Ky, kim Ka, kim D, kim J, kang S(2008). Brand equity in hospital marketing. Journal of business research. $61.75-82$

Kim J, hyun $\mathrm{y}(2010)$. Amodel of investigate the influence of marketing-mix efforts and corporate image on brand equity in the software sector. Industrial marketing management

Kotler, P., \& Pfoertsch, W. (2007). Being known or being one of many: The need for brand management for business -tobusiness companies. Journal of Business and Industrial Marketing, 22(6), 357-362. 